\title{
KS. MAREK KARCZEWSKI
}

Uniwersytet Warmińsko-Mazurski w Olsztynie

https://orcid.org/0000-0001-9435-3832

\section{„ZAISTE PRZYJDE NIEBAWEM" (AP 22,20). KILKA REFLEKSJI NAD ESCHATOLOGIĄ APOKALIPSY ŚW. JANA}

\section{WSTĘP}

Badania naukowe nad Apokalipsą rozwinęły się, począwszy od przełomu XIX i XX wieku, i w drugiej połowie minionego stulecia osiągnęły poziom dojrzały ${ }^{1}$. W ich rozwój mają swój wkład również uznani polscy bibliści². Wydaje się jednak, że w toku dyskusji naukowej na temat historycznego kontekstu powstania księgi, jej specyfiki literackiej, relacji do apokaliptyki judaistycznej itp. coraz częściej pomija się inny ważny aspekt, który stanowi jej eschatologia. Rodzi to pewien niepokój i pytanie, czy nie należałoby na nowo zwrócić uwagi na wymiar eschatologiczny przesłania ostatniej księgi Nowego Testamentu. W poniższym opracowaniu skoncentrowano się na wybranych aspektach badań teologiczno-biblijnych nad eschatologią Ap. Artykuł będzie zawierał trzy punkty. W pierwszym zostanie syntetycznie omówiona relacja między głównymi nurtami studiów nad Ap i badaniami nad nią o charakterze eschatologicznym. Chodzi tu najpierw o toczącą się dyskusję naukową na temat związku eschatologii Ap z kontekstem prześladowań pierwszych chrześcijan. Ponadto zostanie poruszona kwestia relacji badań nad etyką Ap do jej eschatologii. Ostatni problem będzie stanowiło ustalenie relacji między profetyzmem i eschatologią w Ap. W punkcie drugim zostanie postawiona teza, że przesłanie eschatologiczne stanowi główną treść Ap. Nie jest więc możliwe, by pomijając je, dokonać jej całościowej interpretacji. W ostatnim, trzecim punkcie zostaną przedstawione pewne postulaty metodologiczne. Ich uwzględnienie mogłoby ułatwić pogłębioną analizę eschatologii Ap. Chodzi o to, by zauważyć typową

1 Por. wykaz literatury naukowej w: D.E. Aune, Revelation 1-5 (Word Biblical Commentary, t. 52), Nashville: T. Nelson 1997, s. XXVII-XLV; D. Kotecki, Jezus a Bóg Izraela w Apokalipsie św. Jana (Scripta Theologica Thorunensia, t. 27), Torun: Wydawnictwo Naukowe UMK 2013, s. $451-470$.

2 Por. wykaz autorów polskich w: M. Wojciechowski, Apokalipsa świętego Jana (Nowy Komentarz Biblijny Nowy Testament, t. XX), Częstochowa: Święty Paweł 2012, s. 407-449. 
dla Ap dynamikę eschatologiczną. Trzeba pamiętać, że niektóre symbole Ap są w założeniu wieloznaczne. Ponadto w analizie teologiczno-biblijnej eschatologii Ap nie można pomijać jej związku z oryginalną chrystologią i eklezjologią księgi. Opracowanie będzie zatem miało charakter prezentacji autorskich wniosków i postulatów o charakterze metodologicznym.

\section{BADANIA NAUKOWE NAD APOKALIPSĄ I JEJ WYMIAR ESCHATOLOGICZNY}

Istotny problem w badaniach nad Sitz im Leben Ap stanowi ustalenie jej relacji do ówczesnego świata rzymskiego. Ponadto coraz więcej uwagi poświęca się wymiarowi etycznemu i profetycznemu Ap. Czy studia te mają znaczenie w badaniach nad eschatologią Ap?

\subsection{SYTUACJA CHRZEŚCIJAN W CZASACH RZYMSKICH I ESCHATOLOGIA APOKALIPSY}

Jest oczywiste, że podobnie jak pozostałe pisma nowotestamentowe również Ap powstała w kontekście rozwoju chrześcijaństwa w Imperium Rzymskim. W treści Ap można dostrzec liczne możliwe symbole i odniesienia do rzeczywistości imperialnej Rzymu³. Z perspektywy teologiczno-biblijnej studia te są istotne, ponieważ pozwalają lepiej zrozumieć Sitz im Leben tekstu Ap i odnieść jej treść do właściwego kontekstu historycznego. Badania nad relacją Ap - Imperium Rzymskie nie są jednak pozbawione problemów i punktów spornych. Jeden z nich stanowi ocena rzeczywistej sytuacji odbiorców Ap, chrześcijan z Azji Mniejszej i sprawa ich konfliktu ze strukturami imperialnymi. Można wyróżnić trzy zasadnicze

3 Por. D.E. Aune, The Influence of Roman imperial court ceremonial on the Apocalypse of John, „Biblical Research” 28 (1983), s. 5-26; L.L. Thompson, The Book of Revelation. Apocalypse and Empire, New York-Oxford: Oxford University Press 1990; G. Biguzzi, Ephesus, its Artemision, its Temple to the Flavian Emperors, and Idolatry in Revelation, „Novum Testamentum” 40 (1998), nr 3, s. 276-290; S. Friesen, Imperial Cults and the Apocalyse of John, Oxford: Oxford University Press 2001; J.W. van Henten, Dragon myth and imperial ideology in Revelation 12-13, w: D.L. Barr (red.), The Reality if Apocalypse: Rhetoric and Politics in the Book of Revelation (Society of Biblical Literature Symposium Series, t. 39), Atlanta: Society of Biblical Literature 2006, s. 181-203; M. Wojciechowski, Wpływy greckie w Apokalipsie św. Jana, „Biblica et Patristica Thoruniensia” 5 (2012), s. 115-124. 
stanowiska komentatorów zajmujących się tym problemem ${ }^{4}$. Według klasycznej opinii, Ap powstała pod wpływem prześladowań chrześcijan w Imperium Rzymskim. Wskazuje się przy tym na pamięć o prześladowaniach za czasów Nerona i następnych. Symbole bestii z morza i z ziemi (Ap 13) oraz wizja upadku Wielkiej Nierządnicy (Ap 17-18) wiązałyby się z pragnieniem uwolnienia z ucisku i prześladowań ze strony Rzymu. W nowszych opracowaniach wskazuje się na prawdopodobieństwo, że prześladowania miały raczej charakter lokalny. Możliwe, że w czasach redakcji Ap dotyczyły one jedynie terenów Azji Mniejszej. Trzecia grupa badaczy sugeruje, że represje miały charakter sporadyczny i nie wpłynęły na treść Ap w sposób decydujący. Zwolennicy tego poglądu odwołują się do braku źródeł, które mogłyby potwierdzić szczególne nasilenie prześladowań w Efezie i okolicznych miastach. Odpowiedź na pytanie o związki przesłania Ap z imperialnym Rzymem jest istotna. Prowadzi bowiem niekiedy do sprowadzenia przesłania eschatologicznego Ap do poziomu projekcji oczekiwań powstałych po wpływem trudnego położenia pierwotnych wspólnot chrześcijańskich. Eschatologia Ap jest odczytywana wówczas jako efekt reakcji na trudny czas. Zapowiedź upadku Imperium Rzymskiego miałaby dodać odwagi prześladowanym i podtrzymać ich na duchu ${ }^{5}$. W przypadku, gdy temat ucisku i prześladowania nie wpływał w sposób decydujący na treść Ap, bardziej oczywiste staje się, że księga jest proroctwem i mówi o czasach eschatologicznych. Jawi się pytanie, czy prześladowania chrześcijan mogą być jakąś formą uzasadnienia przesłania eschatologicznego Ap. Wydaje się, że hipoteza ta, choć dość popularna, nie uwzględnia faktu, że eschatologia Ap powinna być odczytywana w szerszym kontekście eschatologii biblijnej. Wówczas staje się oczywiste, że wiele z eschatologicznych zapowiedzi nowo- i starotestamentowych znajduje w Ap zapowiedź ostatecznego wypełnienia. Słowem, Rzym to tylko możliwa cząstka Sitz im Leben eschatologii Ap.

\subsection{PROBLEMATYKA ETYCZNO-MORALNA W APOKALIPSIE I JEJ PRZESŁANIE ESCHATOLOGICZNE}

Główny problem etyczny w Ap stanowi walka dobra ze złem. Temat ten wiąże się z zawartą w księdze krytyką przejawów niesprawiedliwości i zapowiedziami

4 Por. D. Warden, Imperial Persecution and the Dating of 1 Peter and Revelation, „Journal of Evangelical Theological Society" 34 (1991), s. 207-208; S. Friesen, Imperial Cults and the Apocalyse of John, s. 145-151; D. Kotecki, Duch Święty w zgromadzeniu liturgicznym w świetle Apokalipsy św. Jana (Rozprawy i Studia Biblijne, t. 26), Warszawa: Vocatio 2006, s. 31-40; M. Wojciechowski, Apokalipsa świętego Jana, s. 88-89.

5 Por. A. Yarbro Collins, Crisis and Catharsis. The Power of Apocalypse, Philadelphia: Westminster, 1984, s. 69-73; E. Schüssler Fiorenza, L’Apocalisse. Visione di un mondo giusto, Brescia: Queriniana 1994, s. 254. 
nadejścia świata sprawiedliwego, wolnego od przejawów zła ${ }^{6}$ Wg Ap, zło zostanie zwyciężone i ostatecznie wyeliminowane ${ }^{7}$. Przesłanie etyczne Ap nawiązuje do sytuacji pierwotnych wspólnot chrześcijańskich w Azji Mniejszej ${ }^{8}$. Jednak w kontekście analiz o charakterze teologiczno-biblijnym wskazuje się również na możliwy ponadczasowy charakter niektórych elementów etyki Ap. Istnieją studia dotyczące na przykład interpretacji niektórych symboli Ap jako zawierających ponadczasową krytykę ubóstwienia bogactwa, propagandy antyreligijnej, absolutyzacji władzy państwowej, przemocy i wykluczenia inaczej myślących ${ }^{9}$. W niektórych opracowaniach monograficznych dotyczących Ap wnioski etyczne zdają się zajmować miejsce treści teologicznych ${ }^{10}$. Koncentrowanie się na przesłaniu etyczno-moralnym księgi nie stoi w sprzeczności z badaniami na jej eschatologią. Refleksja teologiczna nad eschatologią Ap powinna uwzględniać efekty studiów nad przesłaniem etycznym i teologiczno-moralnym księgi. Tematyka funkcjonowania Kościołów, konfrontacji ze strukturami zła, przygotowania na powtórne przyjście Jezusa i tego, co nastąpi potem, wskazuje na ścisły związek przesłania eschatologicznego Ap z jej nauczaniem moralnym. Niemniej jednak przesłanie etyczne ma w Ap inny wymiar niż w pozostałych tekstach nowotestamentowych. W Ap jest ono odczytywane w perspektywie profetycznej ${ }^{11} \mathrm{i}$ w odniesieniu do eschatologii.

\subsection{WYMIAR PROFETYCZNY APOKALIPSY I JEJ ESCHATOLOGIA}

Studia nad wymiarem profetycznym Ap są podejmowane od początku badań naukowych nad księgą. Prowadzone są one na różnych płaszczyznach. Zwraca się uwagę na związki Ap z profetyczną literaturą starotestamentową i pozabiblijną $^{12}$. Analizie poddaje się relację profetyzmu Ap do jej wymiaru liturgiczne-

6 Por. H. Ulland, Die Vision als Radikalisierung der Wirklichkeit in der Apokalypse des Johannes, Tübingen-Basel: Francke 1997; M. Wolter, Christliches Ethos nach der Offenbarung des Johannes, w: F.W. Horn, M. Wolter (red.), Studien zur Johannesoffenbarung und ihrer Auslegung, Neukirchen-Vlyun: Neukirchner Verlag 2005, s. 189-209.

7 Por. J. Nowińska, Motyw walki dobra ze złem w Apokalipsie św. Jana (Rozprawy i Studia Biblijne, t. 27), Warszawa: Vocatio 2006.

8 Por. M. Wojciechowski, Etyka w Apokalipsie św. Jana, w: M. Wróbel (red.), Apokaliptyka wczesnego judaizmu i chrześcijaństwa (Analecta Biblica Lublinensia, t. 6), Lublin: Wydawnictwo KUL 2010, s. 225-235.

9 Por. C. Bedrinan, La dimensión socio-politica del mensaje teológico del Apocalipsis, Roma: Editrice Pontificia Università Gregoriana 1996.

10 Por. E. Schüssler Fiorenza, Babilon the Great: A Rethorical-Political Reading of Revelation 17-18, w: The Reality of Apocalypse, s. 243-269.

11 Por. M. Karczewski, Znaczenie terminu hora (godzina) w Apokalipsie Janowej, „Verbum Vitae" 35 (2019), s. 284-290.

12 Por. B. Kowalski, Die Rezeption des Propheten Ezechiel in der Offenbarung des Johannes, Stuttgart: Verlag Katholisches Bibelwerk 2004; G.K. Beale, S.M. McDonough, Revela- 
$\mathrm{go}^{13}$. Bada się także związki przesłania profetycznego Ap ze złożoną symboliką księgi ${ }^{14}$. Podejmowane są również próby ustalenia relacji wizji prorockich Ap do doświadczeń mistycznych ${ }^{15}$. Inną kwestię stanowi interpretacja teologiczna profetyzmu Ap. Podobnie jak w Starym Testamencie proroctwo może dotyczyć nie tylko odległej, niezdefiniowanej przyszłości eschatologicznej, ale także sytuacji historycznej wspólnoty, do której jest kierowane ${ }^{16}$. Historia interpretacji Ap na przestrzeni dziejów dowodzi jednak, że przesłanie profetyczne księgi nie zawsze było poprawnie rozumiane. Z perspektywy teologicznej Ap jako słowo Boże zachowuje swoją aktualność zawsze. Dotyczy to zarówno zapowiedzi eschatologicznych, jak i proroctwa dla Kościoła dzisiaj ${ }^{17}$. Wydaje się, że radykalne oddzielenie eschatologii i proroctwa w Ap jest niemożliwe. Cała księga stanowi bowiem proroctwo o tym, co musi się stać niebawem (Ap 1,1-3). Nawet proroctwo zachowujące sens upomnienia jest ostatecznie wypowiadane w szerokim kontekście dążenia do eschatologicznego spełnienia.

\section{TEOLOGIA KOŃCA CZASÓW JAKO GŁÓWNA PERSPEKTYWA APOKALIPSY}

Od początku powstania Ap jest uważana w środowisku chrześcijańskim za księgę zapowiadającą nadejście końca świata. Paruzja Chrystusa ${ }^{18}$, której szybkiej realizacji oczekiwali pierwsi chrześcijanie, stanowi jeden z głównych motywów pierwszych wersetów księgi (por. Ap 1,7; Dn 7,13; Za 12,10). Zamyka ją aklamacja

tion, w: G.K. Beale, D.A. Carson (red.), Commentary on the New Testament Use of the Old Testament, Grand Rapids-Nottingham: Baker Academic-Apollo 2007, s. 1081-1158; G.K. Beale, The Use of Daniel in Jewish Apocalyptic Literature and the Revalation of St. John, Eugene: T\&T Clark 2010; M. Karczewski, Reinterpretacja Księgi Rodzaju w Apokalipsie św. Jana (Biblioteka Wydziału Teologii UWM, t. 55), Olsztyn: Wydział Teologii UWM 2010; S. Moyse, The Old Testament Use in the Book of Revelation, Edinburgh: T\&T Clark 2014.

13 Por. D. Kotecki, Duch Święty w zgromadzeniu liturgicznym.

14 Por. Ł. Garbacki, Reinterpretacja Księgi Jeremiasza w Apokalipsie św. Jana, Pelplin: Bernardinum 2018

15 Por. U. Vanni, Linguaggio, simboli ed esperienza mistica nel libro dell'Apocalisse, „Gregorianum" 79 (1998), s. 5-28, 473-501.

16 Por. J. López, La figura de la bestia entre historia y profecia, Roma: Editrice Pontificia Università Gregoriana 1998, s. 253-265.

17 Por. M. Karczewski, „Któż jest podobny do Bestii...?” (Ap 13,4). Struktury władzy między historia i proroctwem w Ap 13, „Śląskie Studia Historyczno-Teologiczne” 41 (2008), nr 2, s. 10-20.

18 Szerzej na ten temat por. A. Jankowski, Eschatologia Nowego Testamentu, Kraków: WAM 2007, s. 35-64. 
„Przyjdź, Panie Jezu”, wyrażająca oczekiwanie na paruzję (Ap 22,17.20). Temat paruzji stanowi bazę teologiczną Ap, chociaż poza Ap 1,7 nie mówi się o niej wprost $^{19}$. Jednak jest oczywiste, że napięcie, niepokój, zniecierpliwienie, które dostrzegalne są w niektórych tekstach księgi, wynikają z przekonania, że Pan powróci ${ }^{20}$. Gwarantem jest sam Bóg, który jest Początkiem i Końcem (Ap 1,8; 21,6), oraz Jezus Chrystus (Ap 1,17; 22,13), Pierwszy i Ostatni (Ap 1,8; 21,6) ${ }^{21}$. Owocem paruzji będą: ostateczne pokonanie sił zła, sąd ostateczny, nadejście nowego nieba i nowej ziemi. Sa to typowe tematy eschatologiczne Ap ${ }^{22}$. Autor księgi przepowiada realizację zapowiedzi eschatologicznych zawartych zarówno w Starym Testamencie, jak i w pozostałych tekstach Nowego Testamentu. Wspólnota chrześcijańska, do której kierowane jest przesłanie Ap, żyje w czasie „pomiędzy” jednym i drugim przyjściem. Doświadcza ona już skutków dzieła zbawczego, które dokonało się w Jezusie Chrystusie. Wraz z Jego śmiercią i zmartwychwstaniem czas eschatologiczny już się rozpoczął ${ }^{23}$. Jednocześnie jednak oczekuje się na jego ostateczne dopełnienie. Treści eschatologiczne rozsiane są w całej księdze. W sposób najbardziej wyrazisty dostrzegalne są w Ap 19-2224. Charakter przełomowy ma symboliczna scena nadejścia nowego nieba i nowej ziemi (Ap 21,1; por. Ag 2,6 LXX; Rz 8,20-22; Flp 3,21) 25, która odnosi się do sytuacji po powtórnym przyjściu Jezusa Chrystusa. Nowa Jerozolima symbolizuje odnowiony świat, w którym wszystko koncentruje się wokół Boga i Baranka. Utracony niegdyś raj, tym razem w stopniu zwielokrotnionym będzie dostępny dla mieszkańców eschatologicznego Miasta (por. Ap 22,1-5; Rdz 2,4b-3,24) ${ }^{26}$. Jest to jedyny w Biblii tak rozbudowany obraz eschatologicznej wspólnoty zbawionych.

19 Niekiedy z momentem paruzji wiąże się tekst Ap 19,11-21 lub inny. Jednak nie mówią one o niej wprost.

20 R. Rubinkiewicz, Eschatologia Księgi Apokalipsy, „Roczniki Teologiczno-Kanoniczne” 30 (1983), z. 1, s. 89-90 mówi o eschatologicznej udręce.

${ }^{21}$ Odniesienie do pierwszej i ostatniej litery alfabetu greckiego sugeruje całkowitą kontrolę nad dziejami ludzkości, por. M. Wojciechowski, Apokalipsa, s. 108-109.

22 Por. R. Rubinkiewicz, Eschatologia Księgi Apokalipsy, s. 85-94; A. Spatafora, Le sens eschatologique de l'Apocalypse de Jean, „Eglise et Théologie” 30 (1999), nr 2, s. 259-278; D. Kotecki, Eschatologia Apokalipsy św. Jana, „Theologica Thorunensia” 6 (2005), s. 21-40; M. Karczewski, Jezioro siarki i ognia w Księdze Apokalipsy św. Jana, „Biblica et Patristica Thorunensia” 5 (2012), s. 103-113; M. Karczewski, Harmagedon (Ap 16,6) w kontekście teologicznym Apokalipsy św. Jana, „Studia Elbląskie” 14 (2013), s. 213-225.

${ }^{23}$ Por. R. Rubinkiewicz, Eschatologia Księgi Apokalipsy, s. 86.

24 Podobnie M. Wojciechowski, Apokalipsa, s. 89.

25 Por. A. Jankowski, Eschatologia Nowego Testamentu, s. 174-175.

26 Por. M. Karczewski, Ogród w centrum miasta? Niektóre aspekty rozwoju symbolu ogrodu Eden w tradycji biblijnej, ,Journal of Urban Ethnology” 18 (2020), s. 155-166. 
W historii badań egzegetycznych podejmowano próby zdefiniowania zawartej w Ap koncepcji czasu ${ }^{27}$. Mówi się niekiedy o tzw. teologii historii ${ }^{28}$ lub oryginalnej koncepcji czasu typowej dla autora księgi ${ }^{29}$. Kwestie te są bardzo złożone. Niektóre jednostki czasu prezentowane w Ap mogą odnosić się do punktowych wydarzeń o charakterze profetycznym. Mogą one mieć także znaczenie czysto symboliczne. Jednak nie da się ich wyłączyć całkowicie z perspektywy eschatologicznej Ap. Ograniczanie przesłania Ap do historycznej sytuacji jej odbiorców wydaje się rozwiązaniem nieadekwatnym do sensu treści księgi ${ }^{30}$. Naturalną perspektywę teologiczną czasu w Ap tworzy i jej profetyzm, i eschatologia.

\section{NIEKTÓRE CECHY ESCHATOLOGII APOKALIPSY}

Eschatologia Ap zachowuje daleko idącą oryginalnośćc ${ }^{31}$. Warto, podejmując badania nad tą tematyką, uwzględnić jej specyficzną dynamikę. Należy też zwrócić uwagę na wieloznaczność niektórych symboli. Ponadto sugeruje się, by przesłanie eschatologiczne Ap odczytywać w relacji do chrystologii i eklezjologii księgi. Warto też pamiętać, że nie wszystkie jej teksty są jasne i oczywiste ${ }^{32}$.

\subsection{DYNAMIKA ESCHATOLOGICZNA APOKALIPSY}

Jedną z najbardziej zawiłych kwestii w studiach nad Ap stanowi ustalenie relacji między jej wewnętrzną strukturą literacką oraz możliwą sekwencją zapowiadanych w niej zdarzeń. Nie jest też oczywiste, czy mamy do czynienia z jakąś formą

27 Szeroko na temat koncepcji czasu w Ap por. M. Karczewski, Znaczenie terminu hora (godzina), s. 279-306; T. Siemieniec, Teologiczna funkcja terminów kairos i chronos w Apokalipsie Janowej, „Verbum Vitae” 35 (2019), s. 307-342.

28 Por. M. Rissi, Was ist und was geschehen soll danach. Die Zeit-und Geschichtsauffassung der Offenbarung des Johannes (Abhandlungen zur Theologie des Alten und Neuen Testaments, t. 46), Zürich: Theologischer Verlag Zürich ${ }^{3} 1965$.

29 Por. A. Jankowski, Biblijna teologia czasu, Tyniec: Wydawnictwo Benedyktynów 2001; D.E. Aune, God and Time in the Apocalypse of John, w: A.A. Das, F.J. Matera (red.), The Forgotten God. Perspectives in Biblical Theology. Essays in Honor of Paul J. Achtemeier on the Occasion of his Seventy-fifth Birthday, Lousiville-London: Westminster John Knox Press 2002, s. 229-248.

30 Por. B.J. Malina, Christ and Time: Swiss or Mediterranean?, „Catholic Biblical Quarterly” 51 (1989), s. 1-30.

31 Por. A. Jankowski, Eschatologia Nowego Testamentu, s. 296-304.

32 Obok kwestii przykładowych, wspomnianych już powyżej, jako wieloznaczność niektórych figur symbolicznych warto przywołać bardzo niejasne, np. wizję tzw. tysiącletniego królestwa i ,pierwszego zmartwychwstania” w Ap 20,1-8. Choć udaje się zrozumieć znaczenie wielu zawartych 
symbolicznej narracji o charakterze linearnym, czy może są to wizje, które należy traktować jako powtórzenia. Zależnie od przyjętego klucza hermeneutycznego można je traktować jako zapowiedzi kolejnych przyszłych wydarzeń, bezpośrednio poprzedzających paruzję, lub jako pewne formy proroctw, które mówią o tym samym na różne sposoby. Same wizje zawarte w Ap 6-19 mogą wskazywać na nieuchronne zbliżane się końca czasów, jednak mogą mieć także inne znaczenia ${ }^{33}$.

Niewątpliwie dynamika zbliżania się końca czasów jest wyrażona w niektórych typowych dla języka Ap sformułowaniach. Należą do nich między innymi:

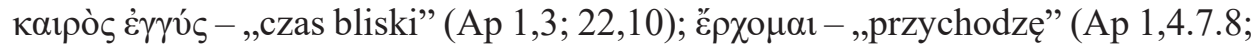

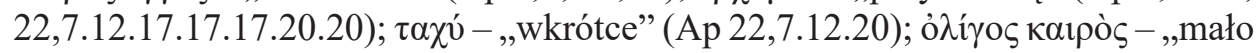
czasu" (Ap 12,12b).

Sformułowanie Kaıpò $\dot{\varepsilon} \gamma \gamma u ́ \varsigma$ - „czas bliski” może być odczytywane w dwóch perspektywach - profetycznej i eschatologicznej. Pojawia się ono w kontekście ogólnego odniesienia do przyszłości, której dotyczy proroctwo księgi (Ap 1,3; $22,10)$. Wskazuje na rozpoczęcie ostatniego etapu dziejów oraz stanowi zarazem wezwanie do przyjęcia właściwej w tej sytuacji postawy ${ }^{34}$.

Termin ع̌ $\rho \chi \mu_{\mu l}$ - ,przychodzę” w sposób najbardziej wyraźny podkreśla dynamikę eschatologiczną Ap. W odniesieniu do Boga i Chrystusa jest on stosowany w następujących kontekstach.

W formie imiesłowowej ó é $\rho \chi o ́ \mu \varepsilon v o \varsigma$ stanowi ostatni z trzech członów określenia Boga w kontekście tzw. wstępnego dialogu liturgicznego (Ap 1,4.8; por. Iz 6,3). Bóg jest tym, „który jest, który był i który przychodzi”. W bardziej dosłownym przekładzie, uwzględniającym specyfikę form gramatycznych, wyrażenie ó $̂ ̀ v$

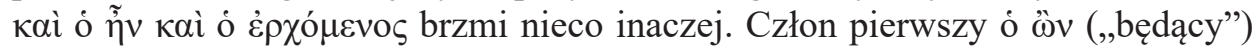
zawiera imiesłów strony czynnej, który wyraża nieustanne trwanie (por. $\mathrm{Wj} 3,14$; LXX: Jr 1,6; 4,10; 14,13; 39,17). Zastosowanie w członie drugim wyrażenia ó ᄁ̃v („który był”) w czasie przeszłym niedokonanym wskazuje na nieokreślony czas

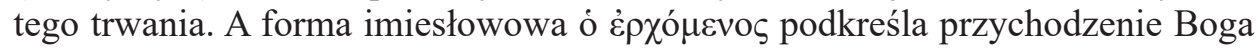
jako stałą Jego cechę. Bóg jest „przychodzący" ${ }^{35}$. Odbiorcy Ap mają wrażenie, że dystans między konkretnym momentem historycznym, w którym się znajdują, a ostatecznym odnowieniem świata nieustannie się zmniejsza. Bezpośrednio do paruzji odnosi się inny fragment wspomnianego dialogu, w którym zastosowano

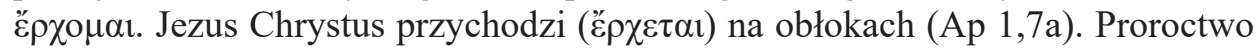
z Dn 7,13 realizuje się w momencie Jego powtórnego przyjścia. Druga część zapowiedzi z Ap 1,7b dotyczy jego publicznego charakteru i reakcji jego świadków. Będą nimi pokuta i lament (por. Za 12,10-14). Akcentowanie faktu, że Jezus już

\footnotetext{
w księdze pojedynczych symboli, istnieją liczne hipotezy dotyczące samego sensu wizji w perspektywie eschatologii Ap, por. M. Wojciechowski, Apokalipsa świętego Jana, s. 358-370.

33 Por. R. Bauckham, La teologia dell'Apocalisse, Brescia: Paideia Editrice 1994, s. 100.

34 Por. M. Wojciechowski, Apokalipsa, s. 98.

35 M. Wojciechowski, Apokalipsa, s. 103 mówi o odcieniu dynamicznym.
} 
przychodzi, podkreśla oczywistość i pewność Jego przyjścia. Jednak pozostała część proroctwa, wyrażona w formach gramatycznych czasu przyszłego, sugeruje, że ma się ono dokonać dopiero w przyszłości. Podkreśla się zatem rozpoczęcie czegoś, co się jeszcze nie dokonało.

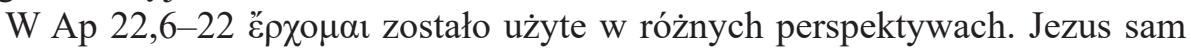
mówi do wizjonera, że niebawem przyjdzie (Ap 22,7.12.20). Ponadto trzykrotnie

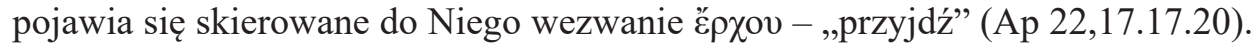

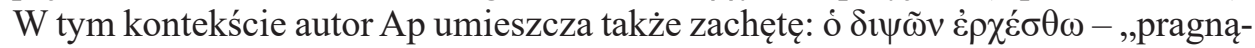

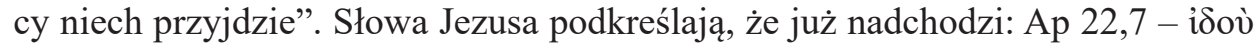

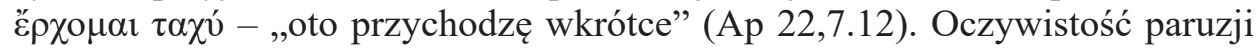
podkreśla użycie partykuły wskazującej ídov̀ - „oto" ${ }^{36}$. W ostatnim zapewnieniu

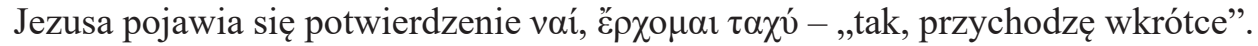

We wszystkich trzech zapowiedziach przyjścia Jezusa (Ap 22,7.12.20) występuje przysłówek $\tau \alpha \chi u ́$ - ,wkrótce”. Termin grecki wyraża brak zwłoki, bezpośrednie wykonanie czynności ${ }^{37}$. Bliska paruzja powinna mobilizować chrześcijan do życia zgodnego z przykazaniami i dobrego moralnie ${ }^{38}$.

Bezpośrednio z dynamiką oczekiwania na powtórne przyjście Jezusa wiążą

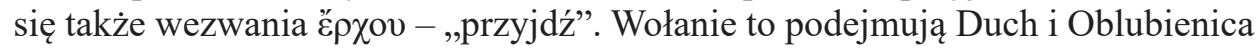
(Ap 22,17) oraz wizjoner (Ap 22,20). Odniesienie do Ducha może stanowić aluzję do perspektywy zbawczej, która czeka na swoje dopełnienie, lub do proroków chrześcijańskich. Oblubienica może wskazywać na Kościół. Bez wątpienia paruzja jest momentem oczekiwanym i upragnionym.

Ostatnie wspomniane powyżej określenie dotyczy czasu działania szatana. Wyrażenie ỏ $\lambda i ́$ yos kaıpò - „mało czasu” (Ap 12,12b) pojawia się w kontekście hymnu w Ap 12,10-12. Zwycięstwo, które Jezus Chrystus odniósł nad szatanem poprzez swoją śmierć, spowodowało, że jego czas działania się kurczy. Mało czasu szatana podkreśla postępującą degradację jego możliwości. Rozwój narracji symbolicznej dotyczącej smoka, głównego symbolu szatana, potwierdza, że jego potencjał słabnie wraz ze zbliżaniem się zwycięstwa Jezusa nad strukturami zła ${ }^{39}$. W odnowionym świecie nie będzie już miejsca na zło.

36 Bardzo często stosowana w Ap dla podkreślenia wagi słów lub wyjątkowości symbolu, por. Ap 12,3.

${ }^{37}$ Por. W. Bauer, Wörterbuch zum Neuen Testament, Berlin-New York: De Gruyter ${ }^{6} 1988$, kol. 1609.

38 Por. M. Wojciechowski, Apokalipsa, s. 395.

39 Por. M. Karczewski, Szatan w Apokalipsie św. Jana, Olsztyn: Wydawnictwo UWM 2013, s. $81-87$. 


\subsection{WIELOZNACZNOŚĆ TREŚCI SYMBOLICZNYCH W APOKALIPSIE}

Jedną z cech Ap jest wieloznaczność niektórych jej symboli. Wieloznaczność ta nie zawsze dotyczy eschatologii księgi. W większości przypadków wynika $\mathrm{z}$ wielości aluzji do więcej niż jednego tekstu biblijnego lub z dynamicznej prezentacji danego symbolu w kontekście $\mathrm{Ap}^{40}$. Wieloznaczność może wiązać się z profetycznym wymiarem księgi ${ }^{41}$. W jej treści można znaleźć jednak figury symboliczne, które mogą mieć również znaczenie eschatologiczne. Może do nich należeć choćby figura wielkiego Babilonu ${ }^{42}$. W perspektywie badań o charakterze literacko-historycznym większość komentatorów podziela pogląd, że wielki Babilon symbolizuje Imperium Rzymskie ${ }^{43}$. Studia nad profetycznym znaczeniem tej figury symbolicznej umożliwiają jednak dostrzeżenie w wielkim Babilonie pewnych cech ponadhistorycznych ${ }^{44}$. Proroctwo o wielkim Babilonie w sposób oczywisty nawiązuje do struktur politycznych o charakterze zdecydowanie wrogim wobec chrześcijaństwa ${ }^{45}$. Tekst Ap 17-18 zapowiadałby zatem nie tylko upadek Imperium Rzymskiego. Sperancyjny charakter Ap 17-18 dotyczyłby także innych sytuacji kryzysowych, w których w różnych etapach historycznych znaleźli się chrześcijanie $^{46}$. Oczywiście, o ile napotkali te cechy, które stanowią podstawę wizerunku Babilonu. W perspektywie eschatologicznej Ap nie da się wykluczyć sytuacji, że wielki Babilon ujawni się także przed paruzją Jezusa Chrystusa. Wskazuje na to opis wesela Baranka w Ap 19,1-9, który może być odczytywany w kluczu eschatologicznym ${ }^{47}$. Wyrażana tu radość z upadku Babilonu nie osiąga swojej pełni ani w upadku Imperium Rzymskiego, ani żadnej innej, podobnej, zwróconej przeciwko Bogu i chrześcijaństwu struktury polityczno-gospodarczej, ale dopiero w momencie ostatecznego wypełnienia oczekiwań eschatologicznych.

40 Por. M. Karczewski, Symbol węża w Apokalipsie św. Jana, „Studia Nauk Teologicznych PAN” 14 (2019), s. 121-137.

41 Por. R. Bauckham, La teologia dell'Apocalisse, s. 170-186.

42 Szeroko na ten temat pisze S. Witkowski, ,Wielki Babilon” w Janowej Apokalipsie jako kryptonim imperialnego Rzymu oraz wrogiego Bogu świata, Kraków: Wydawnictwo La Salette 2012.

43 Por. M. Karczewski, Wyjście z Babilonu w świetle Ap 18,4b-5, w: W. Chrostowski, B. Strza1kowska (red.), Patrzmy na Jezusa, który nam w wierze przewodzi. Księga pamiątkowa dla Księdza Profesora Jana Lacha w 85. rocznicę urodzin, Warszawa: Vocatio 2012, s. 238-249.

44 Papieska Komisja Biblijna, Biblia a moralność. Biblijne korzenie postępowania chrześcijańskiego, Kielce: Verbum 2009, s. 160-164 (nr 116-119) wskazuje na ponadczasowy charakter przesłania Ap dotyczącego systemów antychrześcijańskich o tendencjach totalitarnych, absolutyzacji władzy politycznej oraz iluzorycznej samowystarczalności.

45 Por. M. Karczewski, Krytyka imperialnego Rzymu w Apokalipsie św. Jana we wspótczesnych interpretacjach egzegetycznych, „Horyzonty Polityki” 11 (2020), z. 34, s. 109-123.

46 Por. R. Bauckham, La teologia dell'Apocalisse, s. 187-193.

47 Por. M. Karczewski, ,B Blogosławieni wezwani na ucztę godów Baranka” (Ap 19,9a). Liturgiczne zaproszenie do komunii świętej i jej tło eschatologiczno-biblijne, w: S. Ewertowski (red.), Scio, cui credidi. Księga pamiątkowa ku czci ks. bpa Józefa Wysockiego w 50. rocznicę posługi kapłańskiej, Olsztyn-Elbląg: Wydział Teologii UWM 2015, s. 147-162. 
Te same uwagi mogą dotyczyć niektórych innych obrazów odnoszących się na przykład do wystąpienia dwóch Świadków, kataklizmów i innych wydarzeń symbolicznych.

\subsection{ESCHATOLOGIA APOKALIPSY W RELACJI DO JEJ CHRYSTOLOGII I EKLEZJOLOGII}

Nie ma wątpliwości, że głównym bohaterem Ap jest zmartwychwstały Jezus Chrystus. W Ap 4-22 jest On przedstawiany w sposób symboliczny jako Baranek ${ }^{48}$ - w relacji do Boga lub w perspektywie trynitarnej do Boga i Ducha. Badania nad chrystologią Ap wskazują, że można ją zdefiniować jako chrystologię teocentryczną ${ }^{49}$. Jezus Chrystus nie tylko dokonał dzieła zbawienia w imię Boga, ale posiada również boską godność ${ }^{50}$. W wizji z Ap 4-5 Baranek odbiera taką samą cześć jak Bóg. Baranek przedstawiony jest jako Zbawiciel, zmartwychwstały Pan historii. Także w innych tekstach księgi wskazuje się na boskość Jezusa (por. Ap 6,16; 7,10; 11,1-13; 11,15; 12,10; 14,1; 19,13 itd.). Jemu przysługuje tytuł „Król królów i Pan panów" (Ap 17,14; 19,16) ${ }^{51}$. On jest ostatecznym Sędzią̨2 (Ap 19,11-21; 22,12). W Ap 22,13 znane z 1,4 określenie Boga zostaje przedstawione jako tytuły samego

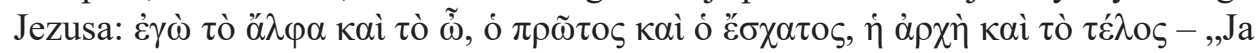
[jestem] Alfa i Omega; Pierwszy i Ostatni, Początek i Koniec". W Jezusie Chrystusie wypełnia się plan Boga. W perspektywie eschatologicznej ten plan osiągnie swoją kulminację $e^{53}$.

Ap jest pismem skierowanym do wspólnoty eklezjalnej. Sam autor postrzega siebie jako jej członka (Ap 1,9). Proroctwo Ap jest osadzone w kontekście wspólnoty, która zbiera się na liturgii (Ap 1,3). Prorok zwraca się do wspólnoty kościelnej, która jest świadoma wyjątkowej więzi z Chrystusem (Ap 1,4-8). Kontekst eklezjalny stanowi naturalną cechę Ap. Kościół jest szczególną własnością zmartwychwstałego Jezusa. Od Niego bierze początek. Bliski związek Jezusa z Kościołem wyrażają symbole siedmiu gwiazd i siedmiu świeczników w Ap 1,9-20. W Ap 2-3

${ }^{48}$ Por. M. Karczewski, Baranek w Apokalipsie św. Jana, Olsztyn: Wydział Teologii UWM 2016.

49 Termin zaproponował D. Kotecki, Reinterpretación del Antiguo Testamento en el Nuevo: cristología teocéntrica en el Apocalipsis de san Juan, „Scritura Theologica” 40 (2008), nr 2, s. 509-524.

${ }_{50}$ D. Kotecki, Jezus a Bóg Izraela, s. 430.

51 Por. M. Karczewski, Jezus Chrystus jako Król królów i Pan panów (Ap 17,14b; 19,16) na tle teologii Apokalipsy, w: A. Paciorek, A. Czaja, A. Tronina (red.), Ewangelia o królestwie (Scripturae Lumen, t. 1), Lublin: Wydawnictwo KUL 2009, s. 265-281.

52 Por. D. Kotecki, Jezus a Bóg Izraela, s. 434-435.

53 Por. A. Jankowski, Jam Alfa i Omega (Ap 22,13). Dopowiedzeń chrystologii biblijnej wydanie drugie rozszerzone, Kraków: WAM 2000. 
Jezus sam upomina swoje Kościoły ${ }^{54}$. Podobnie jak przypadku symboli demonicznych również w Listach zawarte są ponadczasowe informacje o charakterze teologicznym ${ }^{55}$. Warto także zauważyć, że element końcowy w ich wewnętrznej strukturze literackiej stanowi tzw. obietnica dla zwycięzcy. Wszystkie te obietnice dotyczą rzeczywistości eschatologicznej ${ }^{56}$. Jako wspólnota liturgiczna Kościół nie tylko słucha proroctwa Jana. Pierwsi chrześcijanie zebrani na liturgii dzięki wizjom proroka współuczestniczą w liturgii niebiańskiej ${ }^{57}$. Są także zaproszeni do interpretowania treści profetycznych ${ }^{58}$. Właśnie ich dotyczą zapowiedzi eschatologiczne Ap. Wołanie Kościoła: „Przyjdź Panie Jezu” (Ap 22,20) wyraża pragnienie Kościoła oczekującego na ostateczną realizację królowania Jezusa Chrystusa. To królowanie dokonuje się już we wspólnocie wierzących. Osiąga swoją kulminację w Kościele tryumfującym, we wspólnocie zbawionych $($ Ap 12,12). Pierwotny Kościół ponosi konsekwencje wiernego trwania przy Jezusie w oczekiwaniu na Jego powtórne przyjście $^{59}$. Musi mierzyć się z potęgą struktur zwróconych przeciw Bogu i Jezusowi Chrystusowi (Ap 2-3; 12-13; 17-18). Toczy walkę z siłami zła (Ap 12,17). Dotyczy ona nie tylko wytrwania w momencie prześladowań ${ }^{60}$. To także starania o zachowanie odpowiedniego poziomu moralnego, wewnętrzną wierność, unikanie błędu i grzechu ${ }^{61}$. Dzieje się tak, by być przygotowanym na eschatologiczne zaślubiny z Barankiem (Ap 19,1-9). Właśnie perspektywa eschatologiczna rzuca światło na aktualną sytuację Kościoła w drodze do pełni ${ }^{62}$.

${ }^{54}$ Por. T. Siemieniec, Zagrożenia wiary i sposoby ich przezwyciężania w świetle listów do Kościołów (Ap 2-3), w: M. Kowalski (red.), Od wiary Abrahama do wiary Kościoła (Analecta Biblica Lublinensia, t. 11), Lublin: Wydawnictwo KUL 2014, s. 175-214.

55 Por. Papieska Komisja Biblijna, Biblia i moralność, s. 104 (nr 72).

56 Por. D. Kotecki, Jezus a Bóg Izraela, s. 248.

57 Obrazy symboliczne Ap zawierają często wewnętrzną dynamikę, stopniowo dodawane są nowe informacje, a odbiorcy przesłania są stymulowani do ich współtworzenia i interpretacji, por. M. Karczewski, Reinterpretacja Księgi Rodzaju, s. 37-41; D. Kotecki, Jezus a Bóg Izraela, s. 271; J. Nowińska, Co styszysz poza stowem? Sound design Apokalipsy św. Jana (Rozprawy i Studia Biblijne, t. 47), Warszawa: Vocatio 2016, s. 101-137.

58 Por. P. Podeszwa, Paschalna pamięć o Jezusie. Studium egzegetyczno-teologiczne wyrażenia hè martyria Ièsou w Apokalipsie św. Jana (Studia i Materiały - Uniwersytet im. Adama Mickiewicza, Wydział Teologiczny, t. 142), Poznań: Uniwersytet im. Adama Mickiewicza 2011, s. 356-364.

59 Por. A. Jankowski, Eschatologia Nowego Testamentu, s. 302-303.

${ }_{60}$ Por. M. Karczewski, Wytrwałość chrześcijan w Liście do Kościoła w Efezie (Ap 2,1-6), w: W. Chrostowski (red.), Przybliżyto się Królestwo Boże. Księga pamiątkowa dla Księdza Profesora Romana Bartnickiego w 65. rocznice urodzin, Warszawa: Vocatio 2008, s. 192-204.

${ }^{61}$ Wspólnota wierzących żyje i działa w perspektywie eschatologicznej, por. R. Rubinkiewicz, Eschatologia Księgi Apokalipsy, s. 94.

62 Por. M. Wojciechowski, Apokalipsa, s. 85. 


\title{
5. PODSUMOWANIE
}

Temat powyższego opracowania zawiera cytat z ostatniego wersetu Ap. Stanowi on odpowiedź na tęsknotę wyrażaną przez zebraną na liturgii pierwotną wspólnotę chrześcijańską. Apokalipsa św. Jana zachwyca bogactwem i głębią treści eschatologicznych. Ich interpretacja nie jest prosta. Aktualnie w przestrzeni teologicznej refleksji naukowej tematy eschatologiczne nie są podejmowane zbyt często. Refleksje zawarte w tym artykule stanowią formę wskazówek o charakterze metodologicznym. Dotyczą one procesu odczytywania eschatologii Ap. Nie można jej interpretować w oderwaniu od badań o charakterze historycznym i etycznym. Należy uwzględnić specyficzny charakter profetyzmu Ap. Trzeba jednak zdawać sobie sprawę, że w tej księdze eschatologia odgrywa centralną rolę. Stąd propozycje, by w przestrzeni badań teologicznych nad Ap uwzględnić niektóre aspekty jej przesłania eschatologicznego. Omówiono tu syntetycznie kwestie dynamiki eschatologicznej Ap, wieloznaczności niektórych zawartych w niej symboli oraz konieczności uwzględnienia oryginalnej chrystologii i eklezjologii. Przedstawione refleksje i postulaty z pewnością nie wyczerpują tematu interpretacji eschatologii Ap. Jednak należy wyrazić nadzieję, że będą stanowiły nie tylko formę pomocy w studium eschatologii Ap, ale również dodadzą odwagi tym biblistom i teologom, dla których tematyka eschatologiczna księgi pozostaje jeszcze terra incognita. Analiza naukowa Ap osiąga bowiem swoje apogeum w odkrywaniu głównego nurtu przekazu księgi, który bez wątpienia stanowi jej eschatologia.

\author{
„ZAISTE PRZYJDĘ NIEBAWEM” (AP 22,20). \\ KILKA REFLEKSJI NAD ESCHATOLOGIA \\ APOKALIPSY ŚW. JANA
}

Streszczenie

Apokalipsa św. Jana zachwyca bogactwem i głębią treści eschatologicznych. Jednak aktualnie w przestrzeni teologiczno-biblijnej refleksji naukowej tematy eschatologiczne nie są podejmowane zbyt często. Refleksje zawarte w tym artykule stanowią formę wskazówek o charakterze metodologicznym. Dotyczą one procesu odczytywania eschatologii Ap. Nie można jej interpretować w oderwaniu od badań o charakterze historyczno-literackim czy badań nad etyką księgi. Należy uwzględnić także specyficzny charakter profetyzmu Ap. Jednak centralne miejsce zajmują w Ap treści eschatologiczne. Aby interpretować je właściwie, warto uwzględnić niektóre postulaty. Należą do nich: zwrócenie uwagi na dynamikę eschatologiczną Ap, uwzględnienie wieloznaczności niektórych symboli oraz odczytanie eschatologii księgi w relacji do jej oryginalnej chrystologii i eklezjologii.

Słowa kluczowe: Apokalipsa św. Jana, eschatologia Apokalipsy, profetyzm Apokalipsy, teologia Apokalipsy. 


\title{
"I WILL COME SOON" (REV 22:20). \\ SOME REFLECTIONS ON THE ESCHATOLOGY \\ OF THE APOCALYPSE OF ST. JOHN
}

\begin{abstract}
Summary
The Apocalypse of St. Jana delights with the richness of eschatological content. However, the eschatological themes of the Apocalypse are not a frequent subject of scientific study. The reflections contained in this article take the form of methodological guidelines. They concern the process of interpreting the eschatology of Apocalypse. The Apocalypse should not be interpreted in isolation from historical and literary research. It should also not be interpreted in isolation from ethical research. It should also take into account the specific nature of prophetism of the Apocalypse. Eschatological contents contain an important place in this book. In order to interpret them properly, it is necessary to note i.a.: eschatological dynamics of the Apocalypse; the ambiguity of some symbols; the relation of eschatology to christology and ecclesiology.
\end{abstract}

K e y w o r d s: Apocalypse of St. John, Eschatology of Revelation, Prophetism of Revelation, Theology of Revelation.

\section{„ICH WERDE IN DER TAT BALD KOMMEN“ (OFFB 22, 20). \\ EINIGE REFLEXIONEN ÜBER DIE ESCHATOLOGIE DER APOKALYPSE DES HEILIGEN JOHANNES}

\section{Zusammenfassung}

Die Apokalypse des heiligen Johannes beeindruckt durch den Reichtum und die Tiefe ihres eschatologischen Inhalts. Allerdings werden derzeit im Raum der theologisch-bibelwissenschaftlichen Reflexion eschatologische Themen nicht allzu oft aufgegriffen. Die in diesem Artikel enthaltenen Überlegungen sind eine Form der methodischen Anleitung. Sie betreffen den Prozess der Lektüre der Eschatologie der Johanneischen Offenbarung. Sie kann nicht isoliert von der historisch-literarischen Forschung oder der Forschung über die Ethik des Buches interpretiert werden. Man sollte auch den spezifischen Prophezeiungscharakter der Apokalypse berücksichtigen. Eschatologische Aspekte nehmen jedoch den zentralen Platz in der Johanneischen Offenbarung ein. Um sie richtig interpretieren zu können, sollten einige Postulate beachtet werden. Dazu gehören: die Beachtung der eschatologischen Dynamik des Buches, die Berücksichtigung der Mehrdeutigkeit einiger Symbole und die Lektüre der Eschatologie des Buches im Verhältnis zu seiner ursprünglichen Christologie und Ekklesiologie.

S chlüss e lw örter: Apokalypse des Heiligen Johannes, Eschatologie der Apokalypse, Prophetie der Apokalypse, Theologie der Apokalypse. 


\section{BIBLIOGRAFIA}

Aune D.E., God and Time in the Apocalypse of John, w: A.A. Das, F.J. Matera (red.), The Forgotten God. Perspectives in Biblical Theology. Essays in Honor of Paul J. Achtemeier on the Occasion of his Seventy-fifth Birthday, Lousiville-London: Westminster John Knox Press 2002, s. 229-248.

Aune D.E., Revelation 1-5 (Word Biblical Commentary, t. 52), Nashville: T. Nelson 1997.

Aune D.E., The Influence of Roman imperial court ceremonial on the Apocalypse of John, „Biblical Research” 28 (1983), s. 5-26.

Bauckham R., La teologia dell'Apocalisse, Brescia: Paideia Editrice 1994.

Bauer W., Wörterbuch zum Neuen Testament, Berlin-New York: De Gruyter ${ }^{6} 1988$.

Beale G.K., The Use of Daniel in Jewish Apocalyptic Literature and the Revalation of St. John, Eugene: T\&T Clark 2010.

Beale G.K., McDonough S.M., Revelation, w: G.K. Beale, D.A. Carson (red.), Commentary on the New Testament Use of the Old Testament, Grand Rapids-Nottingham: Baker Academic-Apollo 2007, s. 1081-1158.

Bedrinan C., La dimensión socio-politica del mensaje teológico del Apocalipsis, Roma: Editrice Pontificia Università Gregoriana 1996.

Biguzzi G., Ephesus, its Artemision, its Temple to the Flavian Emperors, and Idolatry in Revelation, „Novum Testamentum” 40 (1998), nr 3, s. 276-290.

Friesen S., Imperial Cults and the Apocalyse of John, Oxford: Oxford University Press 2001.

Garbacki Ł., Reinterpretacja Księgi Jeremiasza w Apokalipsie św. Jana, Pelplin: Bernardinum 2018.

Henten van J.W., Dragon myth and imperial ideology in Revelation 12-13, w: D.L. Barr (red.), The Reality if Apocalypse: Rhetoric and Politics int Book of Revelation (Society of Biblical Literature Symposium Series, t. 39), Atlanta: Society of Biblical Literature 2006, s. 181-203.

Jankowski A., Biblijna teologia czasu, Tyniec: Wydawnictwo Benedyktynów 2001.

Jankowski A., Eschatologia Nowego Testamentu, Kraków: WAM 2007.

Jankowski A., Jam Alfa i Omega (Ap 22,13). Dopowiedzeń chrystologii biblijnej wydanie drugie rozszerzone, Kraków: WAM 2000.

Karczewski M., Baranek w Apokalipsie św. Jana, Olsztyn: Wydział Teologii UWM 2016.

Karczewski M., „Błogosławieni wezwani na uczte godów Baranka” (Ap 19,9a). Liturgiczne zaproszenie do komunii świętej i jej tło eschatologiczno-biblijne, w: S. Ewertowski (red.), Scio, cui credidi. Księga pamiątkowa ku czci ks. bpa Józefa Wysockiego w 50. rocznice posługi kapłańskiej, Olsztyn-Elbląg: Wydział Teologii UWM 2015, s. $147-162$.

Karczewski M., Harmagedon (Ap 16,6) w kontekście teologicznym Apokalipsy św. Jana, „Studia Elbląskie” 14 (2013), s. 213-225.

Karczewski M., Jezioro siarki i ognia w Księdze Apokalipsy św. Jana, „Biblica et Patristica Thorunensia" 5 (2012), s. 103-113.

Karczewski M., Jezus Chrystus jako Król królów i Pan panów (Ap 17,14b; 19,16) na tle teologii Apokalipsy, w: A. Paciorek, A. Czaja, A. Tronina (red.), Ewangelia o królestwie (Scripturae Lumen, t. 1), Lublin: Wydawnictwo KUL 2009, s. 265-281. 
Karczewski M., Krytyka imperialnego Rzymu w Apokalipsie św. Jana we współczesnych interpretacjach egzegetycznych, „Horyzonty Polityki” 11 (2020), z. 34, s. 109-123.

Karczewski M., „Któż jest podobny do Bestii...?” (Ap 13,4). Struktury władzy między historia i proroctwem w Ap 13, „Śląskie Studia Historyczno-Teologiczne” 41 (2008), nr 2, s. 10-20.

Karczewski M., Ogród w centrum miasta? Niektóre aspekty rozwoju symbolu ogrodu Eden w tradycji biblijnej, „Journal of Urban Ethnology” 18 (2020), s. 155-166.

Karczewski M., Reinterpretacja Księgi Rodzaju w Apokalipsie św. Jana (Biblioteka Wydziału Teologii UWM), Olsztyn: Wydział Teologii UWM 2010.

Karczewski M., Symbol węża w Apokalipsie św. Jana, „Studia Nauk Teologicznych PAN” 14 (2019), s. 121-137.

Karczewski M., Szatan w Apokalipsie św. Jana, Olsztyn: Wydawnictwo UWM 2013.

Karczewski M., Wyjście z Babilonu w świetle Ap 18,4b-5, w: W. Chrostowski, B. Strzałkowska (red.), Patrzmy na Jezusa, który nam w wierze przewodzi. Księga pamiątkowa dla Księdza Profesora Jana Łacha w 85. rocznicę urodzin, Warszawa: Vocatio 2012, s. 238-249.

Karczewski M., Wytrwałość chrześcijan w Liście do Kościoła w Efezie (Ap 2,1-6), w: W. Chrostowski, Przybliżyto się Królestwo Boże. Księga pamiatkowa dla Księdza Profesora Romana Bartnickiego w 65. rocznice urodzin, Warszawa: Vocatio 2008, s. 192-204.

Karczewski M., Znaczenie terminu hora (godzina) w Apokalipsie Janowej, „Verbum Vitae” 35 (2019), s. 279-306.

Kotecki D., Duch Święty w zgromadzeniu liturgicznym w świetle Apokalipsy św. Jana (Rozprawy i Studia Biblijne, t. 26), Warszawa: Vocatio 2006.

Kotecki D., Eschatologia Apokalipsy św. Jana, ,Theologica Thorunensia” 6 (2005), s. 21 40.

Kotecki D., Jezus a Bóg Izraela w Apokalipsie św. Jana (Scripta Theologica Thorunensia, t. 27), Toruń: Wydawnictwo Naukowe UMK 2013.

Kotecki D., Reinterpretación del Antiguo Testamento en el Nuevo: cristología teocéntrica en el Apocalipsis de san Juan, „Scritura Theologica” 40 (2008), nr 2, s. 509-524.

Kowalski B., Die Rezeption des Propheten Ezechiel in der Offenbarung des Johannes, Stuttgart: Verlag Katholisches Bibelwerk 2004.

López J., La figura de la bestia entre historia y profecia, Roma: Editrice Pontificia Università Gregoriana 1998.

Malina B.J., Christ and Time: Swiss or Mediterranean?, „Catholic Biblical Quarterly” 51 (1989), s. 1-30.

Moyse S., The Old Testament Use in the Book of Revelation, Edinburgh: T\&T Clark 2014.

Nowińska J., Co styszysz poza słowem? Sound design Apokalipsy św. Jana (Rozprawy i Studia Biblijne, t. 47), Warszawa: Vocatio 2016.

Nowińska J., Motyw walki dobra ze złem w Apokalipsie św. Jana (Rozprawy i Studia Biblijne, t. 27), Warszawa: Vocatio 2006.

Papieska Komisja Biblijna, Biblia a moralność. Biblijne korzenie postępowania chrześcijańskiego, Kielce: Verbum 2009.

Podeszwa P., Paschalna pamięć o Jezusie. Studium egzegetyczno-teologiczne wyrażenia hē martyria Ièsou w Apokalipsie św. Jana (Studia i Materiały - Uniwersytet im. Adama 
Mickiewicza, Wydział Teologiczny, t. 142), Poznań: Uniwersytet im. Adama Mickiewicza 2011.

Rissi M., Was ist und was geschehen soll danach. Die Zeit - und Geschichtsauffassung der Offenbarung des Johannes (Abhandlungen zur Theologie des Alten und Neuen Testaments, t. 46), Zürich: Theologischer Verlag Zürich ${ }^{3} 1965$.

Rubinkiewicz R., Eschatologia Ksiegi Apokalipsy, „Roczniki Teologiczno-Kanoniczne” 30 (1983), z. 1, s. 85-94.

Schüssler Fiorenza E., Babilon the Great: A Rethorical-Political Reading of Revelation 17-18, w: D.L. Barr (red.), The Reality if Apocalypse: Rhetoric and Politics in the Book of Revelation (Society of Biblical Literature Symposium Series, t. 39), Atlanta: Society of Biblical Literature 2006, s. 243-269.

Schüssler Fiorenza E., L'Apocalisse. Visione di un mondo giusto, Brescia: Queriniana 1994. Spatafora A., Le sens eschatologique de l'Apocalypse de Jean, „Eglise et Théologie” 30 (1999), nr 2, s. 259-278.

Siemieniec T., Teologiczna funkcja terminów kairos i chronos w Apokalipsie Janowej, „Verbum Vitae” 35 (2019), s. 307-342.

Siemieniec T., Zagrożenia wiary i sposoby ich przezwyciężania w świetle listów do Kościotów (Ap 2-3), w: M. Kowalski (red.), Od wiary Abrahama do wiary Kościoła (Analecta Biblica Lublinensia, t. 11), Lublin: Wydawnictwo KUL 2014, s. 175-214.

Thompson L.L., The Book of Revelation. Apocalypse and Empire, New York-Oxford: Oxford University Press 1990.

Ulland H., Die Vision als Radikalisierung der Wirklichkeit in der Apokalypse des Johannes, Tübingen-Basel: Francke 1997.

Vanni U., Linguaggio, simboli ed esperienza mistica nel libro dell'Apocalisse, „Gregorianum" 79 (1998), s. 5-28, 473-501.

Warden D., Imperial Persecution and the Dating of 1 Peter and Revelation, „Journal of Evangelical Theological Society" 34 (1991), s. 202-211.

Witkowski S., ,, Wielki Babilon” w Janowej Apokalipsie jako kryptonim imperialnego Rzymu oraz wrogiego Bogu świata, Kraków: Wydawnictwo La Salette 2012.

Wojciechowski M., Apokalipsa świętego Jana (Nowy Komentarz Biblijny Nowy Testament, t. XX), Częstochowa: Święty Paweł 2012.

Wojciechowski M., Etyka w Apokalipsie św. Jana, w: M. Wróbel (red.), Apokaliptyka wczesnego judaizmu i chrześcijaństwa (Analecta Biblica Lublinensia, t. 6), Lublin: Wydawnictwo KUL 2010, s. 225-235.

Wojciechowski W., Wpływy greckie w Apokalipsie św. Jana, „Biblica et Patristica Thoruniensia" 5 (2012), s. 115-124.

Wolter M., Christliches Ethos nach der Offenbarung des Johannes, w: F.W. Horn, M. Wolter (red.), Studien zur Johannesoffenbarung und ihrer Auslegung, Neukirchen-Vlyun: Neukirchner Verlag 2005, s. 189-209.

Yarbro Collins A., Crisis and Catharsis. The Power of Apocalypse, Philadelphia: Westminster 1984. 
Marek Karczewski - duchowny Kościoła rzymskokatolickiego (diecezja elbląska), doktor habilitowany nauk teologicznych, profesor uczelni na Wydziale Teologii Uniwersytetu Warmińsko-Mazurskiego w Olsztynie. W roku 1996 uzyskał stopień licencjata nauk biblijnych w Papieskim Instytucie Biblijnym, a w roku 1999 doktorat z zakresu teologii biblijnej na Papieskim Uniwersytecie Gregoriańskim w Rzymie. Autor kilku książek i kilkudziesięciu artykułów z zakresu egzegezy i teologii biblijnej. Główne kierunki badań: egzegeza i teologia Apokalipsy św. Jana, profetyzm nowotestamentowy i wczesnochrześcijański, hermeneutyka biblijna Jana z Kwidzyna i Johanna Gottfrieda Herdera. Autor monografii: L'altro segno (Ap 12,3). La figura del drago in Ap 12,3-17 e le sue implicazioni teologico-bibliche (1999), Reinterpretacja Ksiegi Rodzaju w Apokalipsie św. Jana (2010), Szatan w Apokalipsie św. Jana (2013), Baranek w Apokalipsie św. Jana (2016), Piotr Apostot w Nowym Testamencie (2020). Adres do korespondencji: marek. karczewski@uwm.edu.pl. 